Orbis Tertius, vol. XXVI, nº 34, e213, noviembre 2021 - abril 2022. ISSN 1851-7811

Universidad Nacional de La Plata

Facultad de Humanidades y Ciencias de la Educación

Centro de Estudios de Teoría y Crítica Literaria

\title{
El Archivo Colonial revisitado. Presentación
}

\author{
Beatriz Colombi \\ beacolombi@yahoo.com.ar \\ Universidad de Buenos Aires, Argentina
}

\section{Valeria Añón}

valeunlp@gmail.com

Instituto de Investigaciones en Humanidades y Ciencias Sociales (UNLP - CONICET).

Facultad de Humanidades y Ciencias de la Educación. Universidad Nacional de La Plata,

Argentina

Cita sugerida: Colombi, B. y Añón, V. (2021). El

Archivo Colonial revisitado. Presentación. Orbis Tertius,

26(34), e213. https://doi.org/10.24215/18517811e213

\section{EL ARCHIVO}

\section{Desconcertante y colosal, sin embargo el archivo atrapa. (...) El archivo es una desgarradura en el tejido de los dias, el bosquejo realizado de un acontecimiento inesperado. \\ Arlette Farge}

En su bello estudio La atracción del archivo (1991), la historiadora francesa acude a la metáfora para definir el archivo y su experiencia: el mar, las mareas y los equinoccios; también el tejido desgarrado, es decir, el tiempo marcado o resquebrajado; la pincelada de lo sorprendente. Se trata de la recurrencia de imágenes que remiten al movimiento, a una dinámica del archivo que, contra ciertas imágenes anquilosadas de fijeza y cerrazón, permite pensarlo como algo viviente: el espacio en el que habitan otras voces, otros textos. Esta supervivencia, azarosa a veces, minuciosamente organizada otras, es aún más potente si pensamos el archivo colonial americano, en particular si lo hacemos desde una perspectiva literaria que atienda a las formas, a las retóricas, a las continuidades y rupturas en una diacronía de gran complejidad. 
El dosier que presentamos aquí retoma estas dimensiones y se inserta en un movimiento de la crítica literaria latinoamericana que, en las últimas décadas, en especial a partir del "cambio de paradigma" que Rolena Adorno (1988) propiciaba para los estudios coloniales, no ha dejado de preguntarse acerca del archivo en sus múltiples dimensiones. Nos referimos a la materialidad y domiciliación (Derrida, 2000); al archivo como ley de enunciación (Foucault, 2000) y como status (Mbembé, 2020); y también a este como génesis de la ficción latinoamericana (González Echevarría, 2000). Pensamos además en el archivo como repertorio y performance (Taylor, 2003) y como hueco y montaje (Didi-Huberman, 2007). Asimismo, y en línea con relevantes investigaciones que se han llevado a cabo en la academia latinoamericana y local (Goldchluk y Pené, 2003; Dalmaroni, 2010; Chicote, 2021), este dosier busca participar en un debate que aún no se ha agotado, aportando las peculiares inflexiones y problemas que los textos coloniales proveen a la literatura. Para ello es preciso, por un lado, revisar el canon consensuado que reguló durante siglos las aproximaciones críticas al archivo colonial. Por el otro lado, se impone retomar la noción de corpus para iluminar las periferias, los bordes, los silencios del archivo, y volver la mirada sobre textos y voces que habían resultado excluidos de los estudios literarios.

En este dosier nos proponemos entonces indagar acerca de la configuración del archivo colonial en un ámbito específico y representativo, la Nueva España, y con un corpus diacrónico que abarca los tres siglos que configuraron aquello que se ha denominado, no sin polémicas, la "colonia". Los trabajos que aquí se presentan entrelazan miradas y disciplinas (la literatura, la historia), centralidades y márgenes del archivo (desde las crónicas mestizas hasta las colecciones novohispanas del siglo XVIII), polémicas y disputas que se gestan en la relectura y en la diacronía. La procedencia de los autores y autoras de las investigaciones aquí incluidas (Argentina, México, Italia y USA) busca ampliar las miradas al tiempo que los reúne bajo una pregunta común: ¿qué puede decirnos el archivo americano hoy sobre la conformación de una literatura y la transformación de subjetividades?

\section{LOS ENSAYOS}

Los cuatro primeros trabajos de este dosier abordan el archivo colonial temprano, entrelazan perspectivas literarias e históricas, y atienden a textos cronísticos de tradición occidental e indígena, varios de ellos periféricos en cuanto a la atención de la crítica. En su ensayo "Tensiones en las crónicas mestizas", María Inés Aldao recupera un texto escasamente abordado en los estudios literarios, la relación de Juan Bautista Pomar, para dar cuenta de sus inflexiones retóricas y formales. La noción de “tensión” le permite mostrar, desde una perspectiva original para este texto, la incipiente formulación de una enunciación mestiza y los modos en que esta socava la colonialidad del archivo temprano. El ensayo de Clementina Battcock, "Una generación de cronistas novohispanos", trae al centro del debate las historias de Hernando Alvarado Tezózomoc, Domingo Francisco de San Antón Muñón Chimalpahin Cuauhtlehuanitzin y Fernando de Alva Ixtlilxóchitl. En la tensión de la prosodia entre el castellano y el náhuatl que ya exhiben los nombres propios se cifra una nueva historiografía y un clivaje en el archivo americano de los siglos XVI y XVII. El trabajo analiza estas historias y sus polémicas, da cuenta de las discusiones post-conquista y de las modulaciones de la colonialidad posterior; recorre las formas en que estos enunciadores se apropian de tradiciones variadas y operan con un archivo autóctono hoy perdido o desmembrado. Así, esta "generación" inscribe en sus historias las huellas de un archivo interpolado y le confiere una tenue supervivencia. En tanto, los ensayos de Patricia Escandón y Aurora Díez-Canedo atienden a otra zona de este archivo temprano, menos reconocida en los estudios novohispanos. El trabajo de Escandón, "La historiografía en los registros de visita: fray Alonso Ponce”, atraviesa una zona periférica y farragosa de este archivo desmesurado al que se refería Farge, y lo despliega, en su minucia, a partir del estudio de un caso, que funciona como metonimia de los documentos burocráticos y sus derroteros. A partir de la figura de fray Ponce y de sus caminos marcados en los registros de visita, el ensayo infiere otras zonas del archivo en las que se inscribe el territorio y las normas que buscan regularlo, las polémicas entre 
distintas instancias y poderes, las tensiones propias de la conformación del poder colonial. En tanto, en el último trabajo de esta zona del dosier, "Destino americano de fray Marcos de Niza", Aurora Díez-Canedo aborda la Relación de este fraile, en el que da cuenta de su ambicioso derrotero por el Noroeste de México en la primera mitad del siglo XVI. A partir de este itinerario y sus vicisitudes, entre las regulaciones de la relación y las licencias del relato de viaje, fray Marcos organiza un relato que exhibe las disputas entre los estamentos del poder colonial, las diversas concepciones sobre el espacio americano y las marcas de lo maravilloso como móvil del viaje. Como vemos, en estos cuatro trabajos se postula una tarea de restitución y de puesta en diálogo entre textos periféricos y crónicas e historias canónicas.

Los tres últimos trabajos de este dosier se refieren a la configuración de un archivo criollo, y toman como objeto de estudio expresiones que van desde la predicación barroca a la escritura de la historia. Con su ensayo "Cuatro formas de construir un predicador en América. Notas para un estudio sobre las conexiones entre predicación barroca y discurso criollo en el siglo XVII", Juan Vitulli indaga en el sermón y su normativa, un género poco abordado en la literatura virreinal, no obstante, central a la hora de analizar la articulación simbólica colonial. A través de la lectura de manuales prescriptivos sobre el arte del sermón, Vitulli inquiere tanto en la procedencia heterogénea de los autores -peninsulares, indianos o criollos-, como en la construcción de un particular lugar enunciativo situado en América. Desde el interior de una de las instituciones donde los letrados coloniales encontraron refugio y expresión, la eclesiástica, estos autores erigen una pose criolla, según el tropo identificado por Vitulli, determinante para convalidar una autoridad enunciativa diferenciada. El letrado criollo, al tiempo que refunda el archivo heredado, incorpora sus reclamos y una consistente apología del genio indiano, para respaldar una imagen respetable y acreditada que regule los discursos formulados desde el Nuevo Mundo. Así, Mariana Rosetti en "La restitución de la narrativa americana en la escritura de Servando Teresa de Mier", analiza el discurso histórico que articula Mier en su Historia de la revolución de la Nueva España (1813). A través de esta obra, Mier da lugar a lo que la autora llama una trama narrativa americana, que reposiciona a América frente a España, acudiendo al argumento de los antiguos pactos entre la Nueva España y la metrópoli, acompañado de un despliegue de recursos retóricos donde prevalecen la ironía y la analogía. Desde un lugar intersticial y negociador con los distintos factores políticos que tensionaban al americano, Mier rediseña el archivo novohispano, e inclusive, americano, leyendo los enunciados (lo ya dicho) conforme a nuevos paradigmas interpretativos. Si los enunciados posibles definen los límites de un archivo, Mier da sedimento a otro repertorio, rotando y desplazando los límites discursivos del ancien regime. El artículo de Luca Salvi "La imaginación del museo. Francisco Xavier Clavigero y la reconfiguración del archivo virreinal”, también se ocupa del discurso histórico a través del análisis de Historia antigua de México de Francisco Xavier Clavigero. Salvi considera a esta obra como un momento de ordenación del archivo novohispano, en el cual Clavigero hace confluir una materialidad parcialmente perdida (el pasado indígena) -que el jesuita recupera a partir de los restos o vestigios de letrados que lo anteceden (Alva Ixtlilxóchitl, Sigüenza y Góngora, Boturini)-, con la documentación hispánica. De este modo, el discurso de la historia consiente un archivo heterogéneo y abre un cauce al mismo tiempo archivístico y museográfico. De allí que un modo particular de rescate del vacío documental autóctono, según propone Salvi, sean las ilustraciones y descripciones que incluye en su Historia, verdaderas colecciones de un museo de bienes culturales inestables o desaparecidos. Interviene así, como el propio Mier, en los presupuestos de la historiografía ilustrada, donde los letrados criollos batallan entre la carencia y la potencialidad.

En síntesis, el derrotero que este dosier ofrece postula una mirada diacrónica que pone en diálogo el archivo colonial novohispano con la literatura y la historiografía posterior. El trabajo con este archivo desafía las nociones de literatura y de crítica más transitadas, y permite leer tanto las potencialidades y los límites de la crítica, como los usos del archivo, aún en buena parte inexplorado, dada su dinámica colosal. 


\section{REFERENCIAS}

Adorno, R. (1988). Nuevas perspectivas en los estudios literarios coloniales. Revista de crítica literaria latinoamericana, $14(28), 11-27$.

Chicote, G. (2021). El archivo entre la materialidad de los objetos y la transformación digital en América Latina. Revista de critica literaria latinoamericana, 47 (93), en prensa.

Dalmaroni, M. (2010). La obra y el resto: literatura y modos del archivo. Revista Telar, (7-8), 9-30.

Derrida, J. (2000 [1994]). Mal de archivo. Madrid: Trotta.

Didi-Huberman, G. (2007). El archivo arde. En G. Didi-Huberman y K. Ebeling (eds.). Das Archiv brennt (pp.7-32). Berlin: Kadmos.

Farge, A. (1991). La atracción del archivo. París: Editions Alfons el Mágnanim-IVEI.

Foucault, M. (2000 [1969]). Arqueología del saber. México: Siglo XXI Editores.

Goldchluk, G. y Pené, M. (comps.) (2003). Palabras de archivo. Santa Fe: Ediciones UNL y CRLA Archivos.

González Echevarría, R. (2000). Mito y archivo. México: FC.

Mbembé, A. (2020 [2002]). El poder del archivo y sus límites. Trad. de Carla Fumagalli. Orbis Tertius, 25 (31).

Taylor, D. (2003). El archivo y el repertorio. Santiago de Chile: UAH. 